NBER WORKING PAPER SERIES

\title{
RENEWABLE ENERGY POLICIES AND TECHNOLOGICAL INNOVATION: EVIDENCE BASED ON PATENT COUNTS
}

\author{
Nick Johnstone \\ Ivan Hascic \\ David Popp \\ Working Paper 13760 \\ http://www.nber.org/papers/w13760
NATIONAL BUREAU OF ECONOMIC RESEARCH
1050 Massachusetts Avenue
Cambridge, MA 02138
January 2008

The authors wish to thank Laurent Clavel and François Marical for valuable inputs to a previous version of this paper. Thanks also to Helene Dernis, Dominique Guellec and Piotr Tulej for provision of the data used in this study. This report is an output from the OECD project on "Environmental Policy and Technological Innovation" (www.oecd.org/env/cpe/firms/innovation). The views contained in this article are those of the authors and may not reflect those of the OECD, its member countries, or the National Bureau of Economic Research.

NBER working papers are circulated for discussion and comment purposes. They have not been peerreviewed or been subject to the review by the NBER Board of Directors that accompanies official NBER publications.

(C) 2008 by Nick Johnstone, Ivan Hascic, and David Popp. All rights reserved. Short sections of text, not to exceed two paragraphs, may be quoted without explicit permission provided that full credit, including $(\odot$ notice, is given to the source. 
Renewable Energy Policies And Technological Innovation: Evidence Based On Patent Counts Nick Johnstone, Ivan Hascic, and David Popp

NBER Working Paper No. 13760

January 2008

JEL No. O34,O38,Q55,Q58

\section{ABSTRACT}

This paper examines the effect of environmental policies on technological innovation in the specific case of renewable energy. The analysis is conducted using patent data on a panel of 25 countries over the period 1978-2003. It is found that public policy plays a significant role in determining patent applications. Different types of policy instruments are effective for different renewable energy sources.

Nick Johnstone

Empirical Policy Analysis Unit OECD Environment Directorate 2 rue Andre Pascal

75775 Paris Cedex 16

France

nick.johnstone@oecd.org

Ivan Hascic

Empirical Policy Analysis Unit OECD Environment Directorate 2 rue André Pascale 75775 Paris Cedex 16 France Ivan.Hascic@oecd.org

\author{
David Popp \\ Associate Professor of Public Administration \\ Syracuse University \\ The Maxwell School \\ 426 Eggers \\ Syracuse, NY 13244-1020 \\ and NBER \\ dcpopp@maxwell.syr.edu
}




\section{Renewable Energy Policies and Technological Innovation: \\ Evidence Based on Patent Counts}

\section{Introduction}

Investment in renewable energy sources - wind, solar, geothermal, ocean, biomass, and waste - can significantly contribute to the realization of public environmental objectives. In addition, it is sometimes argued that increased shares of renewable energy contribute to other public policy objectives, such as greater energy security in the face of uncertain markets for fossil fuels.

Currently, the penetration of renewables, although increasing, remains limited. In the absence of public intervention favoring their development, production costs remain higher than for substitute fossil fuels. Various government policies have been introduced in an effort to reduce costs and accelerate market penetration, such as feed-in tariffs, production quotas, and tax credits. While it is hoped that these policies will stimulate innovation in renewable energy, the relative effectiveness of alternative policies for encouraging innovation has yet to be tested empirically. As such, renewable energy is an interesting context in which to assess the effect of different types of policy measures on technological innovation.

According to the International Energy Agency (IEA 2006a) three generations of renewable energy technologies can be distinguished: (i) First-generation technologies which have already reached maturity, such as hydropower, biomass combustion, and geothermal energy; (ii) Secondgeneration technologies which are undergoing rapid development such as solar energy, wind power, and modern forms of bio-energy; and (iii) Third-generation technologies which are presently in developmental stages such as concentrating solar power, ocean energy, improved geothermal, and integrated bio-energy systems.

The contribution of different renewable energy sources to total energy supply remains limited. In 2004, among the three main regions of the OECD, Europe had the highest share of renewable use in total energy production (6.9\%). In North America (Canada, United States and Mexico) the figure is 5.7\% and for OECD Pacific (Japan, Korea, Australia and New Zealand) it is 3.4\% (IEA 2006b). Solid biomass is the single largest source of renewable energy supply (44.6\%) followed by hydropower 
(34.6\%). The rate of growth of renewable energy supply amongst the OECD countries between 1990 and 2004 has been particularly strong for wind power (23.9\% annually, on average), combustible renewables and waste excluding solid biomass (i.e. renewable municipal waste, biogas, liquid biomass) (12.3\%), and solar energy (incl. solar thermal and solar photovoltaic) (5.7\%) (IEA 2006b). However, the relative importance of slow-growing renewables, such as solid biomass (1.6\%), hydropower $(0.6 \%)$ and geothermal $(0.2 \%)$, means that the overall rate of growth of renewables $(1.3 \%)$ is marginally below the growth rate of total primary energy supply (TPES) (1.4\%).

In order to increase the share of renewable sources in total energy supply, many governments have sought to encourage further development and adoption of renewable energy technologies (see IEA 2004). For instance, a European Union Directive of 2001 (Directive 2001/77/EC) provides a framework for the development of renewable energies in Europe. In March 2007 EU heads of state have agreed to set a binding target for renewable energy use at 20 percent of the EU's total energy needs by 2020. In the United States, federal tax credits for renewable energy were extended in 2006, granting production tax credits for bio-energy, geothermal, wind, solar, and other renewable energy sources (US DOE 2007).

In addition to production tax credits, other measures introduced in different countries include mandatory production quotas, differentiated tariff systems, and tradable certificates. ${ }^{1}$ With the exception of support for research and development, most policies which have been introduced do not provide explicit support for technological innovation. However, by either decreasing the relative price of the use of renewable energy relative to fossil fuels, or by increasing demand for electricity generated from renewable sources, such policy measures will provide increased returns on the identification of more efficient forms of electricity generation using renewable energy sources.

There is some limited empirical evidence to support the more general finding that environmental policies lead to innovation, as reflected in increased patent activity (see Jaffe, Newell and Stavins (2002) for a review of the empirical literature). For instance, Lanjouw and Mody (1996)

\footnotetext{
${ }^{1}$ For details see the IEA 'Renewable Energy Policies and Measures Database' (IEA 2007).
} 
examined the relationship between the number of patents granted and environmental policy stringency, measured in terms of pollution abatement expenditures at the macroeconomic level for Japan, US, and Germany. They found that pollution abatement cost affects the number of patents successfully granted with 1- to 2-year lag. Using US industry-level data, Jaffe and Palmer (1997) extended Lanjouw and Mody's study by incorporating various factors that potentially affect environmental innovation. The study did not support the hypothesis that the number of patents increased in response to environmental regulation. Brunnermeier and Cohen (2003) used US manufacturing industry data and empirically analyzed factors that determined environmental technological innovation. They found that counts of environment-related patents increase as pollution abatement expenditures increase. Moreover, they found that international competition stimulates environmental innovation.

Very few studies have examined the role of policy instrument choice. Using patent data, Popp (2003) examined the effects of the introduction of the tradable permit system for $\mathrm{SO}_{2}$ emissions as part of US Clean Air Act Amendments. Comparing patent applications following the introduction of the tradable permit scheme with those submitted under the previous technology-based regulatory system, he found evidence of the improved removal efficiency of scrubbers. A later paper by Popp (2006) looks at the experience of the US, Japan and Germany with respect to patents for $\mathrm{SO}_{2}$ and $\mathrm{NO}_{\mathrm{x}}$ abatement technologies. He found: (a) a strong influence of 'home bias' in the effect of domestic environmental regulations on patenting; but, also (b) an important role played by foreign innovation in the development of such patents.

In one of the few cross-country studies, De Vries and Withagen (2005) investigated the relationship between environmental policy regarding $\mathrm{SO}_{2}$ and patent applications in relevant patent classifications. Applying three different models which vary according to the manner in which policy stringency is modeled, they found some evidence that strict environmental policies lead to more innovation. However, they recognize that the modeling of environmental policy in their analysis requires further refinement. Moreover, they expressed concerns about their ability to identify all relevant patent classes. 
In this paper, we examine innovations for renewable energy, using a panel data set comprised of 25 countries and 26 years. The case is interesting for a number of reasons. First, the study contributes to the literature in that it has a cross-country focus. As noted, the studies by Popp (2006) and de Vries and Withagen (2005) are the only cross-country studies available. Most importantly, this cross-country focus allows us to examine the effects of a wide variety of policy types, including feedin tariffs, production quotas, and investment subsidies. Third, we study patent activity with respect to a number of different sources of renewable energy (wind, solar, ocean, geothermal, biomass, wasteto-energy), allowing us to observe how the effectiveness of different policy types varies by technology. For instance, encouraging innovation in solar power, which has high costs and is rarely competitive with existing power sources, might require a different set of policy instruments than would be needed to encourage innovation in wind power.

The next section presents the principal hypotheses tested in this paper. The third section presents the data used in the analysis, including data on patents with respect to renewable energy technologies, as well as data on public policy measures and other relevant explanatory variables. The fourth section presents the model specification and empirical results. The paper concludes with a summary of the main results.

\section{Principal hypotheses}

Our goal in this paper is to test the effect of various renewable energy policies on innovation. While the broad notion that environmental policies encourage innovation is well-documented, previous attempts which assess policy types focus on broad categories of policies (e.g. market-based policies versus command and control regulation). However, within these broad categories lie several policy variants, such as price supports, tax credits, and renewable energy mandates, all of which are likely to have different effects on renewable energy innovation.

Our study focuses on high-income countries, many of which have adopted policies to encourage the development of renewable energy. First, in the 1970s, a number of countries introduced support for R\&D. This was followed by investment incentives (third-party financing, investment 
guarantees), taxes (exemptions, rebates), and price-support policies (tariffs, guaranteed prices). More recently, a number of countries have introduced quantity obligations, often followed by certificates in which the obligations are tradable across generators (IEA 2004).

Given differences in cost structures and level of maturity for different renewable energy sources it is likely that the effects of policy measures will vary by energy source. For instance, investment grants might be particularly effective in inducing innovation for renewable energy sources with high fixed costs per $\mathrm{kWh}$. The inherent riskiness of investments in inventive activities and the skewed nature of potential returns mean that lenders may have difficulty assessing potential investments in R\&D (Jaumotte and Pain 2005). Under such conditions, policies which improve access to capital may be particularly important for renewable energy sources such as photovoltaics, ocean energy and waste-to-energy, which have high up-front fixed costs.

In addition, while in theory price-based measures (e.g. feed-in tariffs) and quantity-based measures (e.g. production quotas) with equivalent environmental objectives should have equal effects on innovation, this may not be the case in practice. Due to the significant uncertainty associated with the early stages of technological development, production quotas which guarantee a market might be more effective in inducing innovation for renewable energy sources in which technologies are less mature such as concentrating solar and integrated bio-energy systems. Conversely, price-based policies (such as feed-in tariffs) may be more effective for sources where technologies have reached or are approaching competitiveness with fossil fuel sources, such as wind, biomass and geothermal energy (IEA 2004).

And finally, evidence has shown that the effectiveness of 'voluntary' environmental policy measures depends significantly on the nature and scope of sanctions associated with 'non-compliance' (Morgenstern and Pizer 2007). This will depend, in part, upon the institutional and market characteristics of the regulated entities. In the case of electricity supply the regulated firms are subject to both economic (and not just environmental) regulation, increasing the potential for governments to impose sanctions should the objectives of voluntary approaches not be met. Perhaps more 
significantly, many firms remain in public hands, reducing the need for the introduction of mandatory regulations in order to meet given policy objectives.

In addition to the influence of policy, we control for a number of other factors that are likely to affect incentives for innovation. First and foremost, renewable energy sources are primarily used as intermediate inputs into the production of electricity, which are substitutable with fossil fuels. Based on the induced innovation literature (e.g., Binswanger 1974) relative prices of alternative factor inputs are clearly an important determinant of innovation. Therefore, with rising prices of fossil fuels, there will be incentives to innovate with respect to the generation of electricity from renewable energy sources.

Schmookler (1966) emphasized the role of demand factors in inducing innovation. As with any activity, R\&D is likely to be responsive to profit-making opportunities. As such, with growing markets, the potential to recoup investments will increase. Moreover, due to the 'serendipitous' nature of successful inventive activity, a large market will increase the potential for inventive talent to identify solutions to a given problem (Popp 2006; Scherer and Harhoff 2000). For these reasons successful innovation is more likely in dynamic sectors in fast-growing economies. In the case of renewable energy, fast-growing markets can be identified by growing electricity consumption.

On the supply-side, general scientific capacity (scientific personnel, resources, etc.) is likely to have an important influence on inventive activity in general. Moreover, the propensity of inventors to patent the results of inventive activity is likely to vary across countries and change over time within countries, both because different strategies may be adopted to capture the rents from innovation and because legal conditions may differ across countries and change through time (Jaumotte and Pain 2005). It is, therefore, important to capture the effects of these two factors in the specific case of renewable energy. 


\section{Data}

\section{A. Patent applications}

Given the importance of technological innovation in modern economies, identifying reliable measures of technological innovation has long preoccupied economists. However, there are still very few such measures available. Many potential candidates (e.g. research and development expenditures, number of scientific personnel, etc.) are at best imperfect indicators of the innovative performance of an economy since they focus on inputs.

In this context patents, as an output measure, have emerged as a valuable source of information, reflecting the innovative performance of a firm or an economy in a manner which is attractive to researchers (Griliches 1990). Patent applications provide a wealth of information on the nature of the invention and the applicant. The data is both readily available (if not always in a convenient format), discrete (and thus easily subject to statistical analysis), and can be disaggregated to specific technological areas. Significantly, there are very few examples of economically significant inventions which have not been patented (Dernis and Guellec 2001; Dernis and Kahn 2004).

Patents, issued by national patent offices (usually specialized agencies), give the holder the right to exclude others from the production of a specific good (or from using a specific process) for a defined number of years, which may vary depending upon the nature of the innovation. In order to be eligible for a patent, the innovation must be novel, involve a non-obvious inventive step, and be commercially viable (Dernis and Guellec 2001; Dernis and Kahn 2004).

However, patents are an imperfect measure of technological innovation for a variety of reasons: (a) It is difficult to distinguish between the 'value' of different patents on the basis of patent applications. Most clearly, the use of unweighted patent counts would attribute the same importance to patents for which there were no successful commercial applications with those which are highly profitable; (b) There is variation in the propensity to patent across countries and sectors. This is due in part to the level of protection afforded by the patent, but also to the possibility of protecting monopoly rights by other means depending upon market conditions; and, (c) Differences in patent regimes across countries mean that it is difficult to be certain that one is comparing 'like with like'. For 
instance, some countries would require multiple patents for the same innovation which could be covered by a single patent in other countries. Fortunately, we can control for these country-specific differences in the regressions that follow. Moreover, by focusing on differences in patenting trends across time, Griliches (1990) shows that patents, sorted by their year of application, are strongly correlated with R\&D spending, and thus make a good proxy for innovative activity.

Despite their shortcomings, patent counts are still the best available source of data on innovation which is readily available and comparable across countries. Relevant patents in different subject areas can be identified using the International Patent Classification (IPC) codes, developed at the World Intellectual Property Organisation. This classification system is a hierarchy of codes, structured into different levels. Table 1 gives an idea of the hierarchical structure, taking the example of solar concentrating devices used for the generation of mechanical power. While other classification systems (e.g., commodity or sectoral classifications) may be suitable to study innovation in general, the advantage of the IPC classification is that it is application-based - and thus facilitates identification of 'environmentally-relevant' technology classes.

Based upon an extensive literature review of technology developments in the area of renewable energy, a set of keywords were identified for this study. These were used to determine appropriate IPC codes which relate directly to renewable energy in the areas of wind, solar, geothermal, ocean, biomass, and waste (the complete list of the relevant codes and their definitions is included in the Appendix). Two possible types of error are possible when searching for relevant patents - inclusion of irrelevant patents and exclusion of relevant patents from the selected classifications. In contrast to some other 'environmental' technologies, renewable energy technologies have the advantage that these types of errors are largely minimized because the definition of the relevant patent classifications allows easy identification of the relevant patents. 
Patent counts were generated for each of the IPC classifications using the OECD Patent Database (OECD 2007). ${ }^{2}$ Only patent applications deposited at the European Patent Office (EPO) were included. Through the EPO, the applicant designates as many of the EPO member states for protection as it desires, rather than applying to individual European patent offices among the 32 contributing countries. If the application is successful, the patent is transferred to the individual national patent offices designated for protection in the application. Given that EPO applications are more expensive than applications to national patent offices, inventors typically first file a patent application in their home country, and then apply to the EPO if they desire protection in multiple European countries. However, costs will be much lower by filing with the EPO than if individual applications are made to each country (see Popp 2005). For the purpose of this paper, the EPO data is thus superior to data from national patent offices because the difference in costs provides a quality hurdle which eliminates applications for low-value inventions.

Counts were obtained for all major patenting countries, including non-European countries. While the European market is significant, it is still expected that there will be some bias toward applications from European inventors (see Dernis and Guellec 2001). In the empirical analysis undertaken in this study this bias is addressed through the inclusion of both country fixed effects and a control variable reflecting data on total EPO applications for all technology areas.

Figure 1 shows the total number of patent applications for six renewable energy sources. Geothermal applications fell off dramatically after the late 1970s, while there has been continuous growth in patenting for solar power technologies. Wind power and waste-to-energy exhibit even more rapid growth, particularly since the mid-1990s. There are relatively few patents for ocean and biomass energy, but they have been also increasing. ${ }^{3}$

\footnotetext{
${ }^{2}$ The assistance of Hélène Dernis, OECD Directorate for Science, Technology and Industry, in the collection of the data is gratefully acknowledged.

${ }^{3}$ Interestingly, EPO applications for patents in total increased approximately ten-fold over the period in question, while patents for renewables increased just over four-fold. However, in recent years the
} 
Figure 2 compares total patent applications for a selection of OECD countries which have exhibited significant levels of innovation. Germany has the highest number of patents, but relative to the US and Japan, this partly reflects the 'home bias' in EPO applications. France and the UK both have at least 200 patent applications over the period.

In addition to these countries, there are specific areas in which individual countries have been important innovators for specific renewables. In addition to Germany, Japan and the US (countries which are consistently important for most renewables), other significant innovators for particular sources have included Denmark (wind), Switzerland (solar, geothermal), France (geothermal, biomass, waste), the UK (ocean, biomass and waste), Italy (ocean), Netherlands (wind), and Sweden (ocean).

However, a comparison of patenting activity across countries needs to account for relative differences in the size of countries' economies. In Table 2, the counts are weighted by country's GDP to yield a measure of patent intensity. On this basis, a number of smaller countries such as Denmark, Switzerland, Austria, and Sweden achieve the highest innovation output per unit of GDP. Of the three countries which have the highest absolute counts, only Germany continues to rank consistently in the top five. Japan and the US remain first and third among non-EPO countries, with Australia second.

And finally, differences in general propensity to patent may also affect country's innovative output through its effect on direction of innovation. Since national environmental policies generally complement innovation policies (IPR regimes, etc.), differences in levels of patents across countries may be due to innovation policy, rather than environmental policy. While we control for such effects in our regression analysis, in Table 3 we simply normalize patent counts by the volume of a country's patenting activity overall (in all technological areas). On this basis, countries such as Denmark, Spain, Australia, Austria and Norway achieve the highest innovation output in renewables. Moreover,

rate of growth in the area of renewables has been higher than the rate of growth of total EPO applications. 
several non-EPO countries achieve relatively high innovation output, with Australia, Taiwan and Canada leading the group.

\section{B. Public policy measures}

In this paper, a database of public policies aimed at developing renewable energy sources compiled at the International Energy Agency (IEA) was used to construct alternative policy indicators. Figure 3 provides a graphical representation of the introduction of alternative policy types in various countries (IEA 2004). Each point on the scatter plot represents the year in which a significant example of a particular type of policy instrument was first introduced in that particular country. Six different policy types are distinguished: R\&D; investment incentives (e.g. risk guarantees, grants, low-interest loans); tax incentives (e.g. accelerated depreciation); tariff incentives (e.g. feed-in tariffs); voluntary programs; obligations (e.g. guaranteed markets, production quotas); and, tradable certificates.

Figure 4 gives a first descriptive indication of the relative importance of public policy factors on patenting (total renewable energy patent applications) in selected countries. There is no obvious correlation between the introduction of different policies and 'spikes' in patent activity, except perhaps the introduction of tariffs in Germany (with some lag), obligations and taxes in Denmark, and investment credits in Japan.

Unfortunately due to the heterogeneous nature of the data, it is not possible to construct continuous variables in which the level of 'stringency' (or 'support') is commensurable across policy types and countries. As such, for most of the policy types dummy variables are introduced to capture the effect of the implementation of different policies. First, binary variables are constructed for the different policy types, including R\&D support, tax measures, investment incentives, differentiated tariffs, voluntary programs, quantity obligations, and tradable certificates. The variables take on a value of 0 prior to introduction of the policy, and 1 thereafter. Second, cluster analysis is applied to construct clusters of policy instruments based upon the policy dummies described above. Third, principal component analysis is applied to construct a composite policy variable. These policy 
variables provide a representation of environmental policy framework which is useful for studying the effects of instrument choice on innovation.

This treatment of public policy influences complements the range of measures used previously to reflect regulatory stringency (e.g., pollution abatement and control expenditures, inspection frequency, etc.). However, it is recognized that this does not capture differences in relative stringency (or support) provided by different measures.

One exception is the case of energy R\&D. The IEA's Energy Technology Research and Development Database (IEA 2006c) collects data on national public sector expenditures on $R \& D$ disaggregated by type of renewable energy. Thus, for public R\&D support, we are able to include data on the magnitude, as well as the existence, of support. The sign on this variable is expected to be positive.

\section{Other explanatory variables}

As noted, returns on innovation are affected by the potential market for this innovation. In the case of renewable energy this is best reflected in trends for electricity consumption. A growing market for electricity should increase incentives to innovate with respect to renewable energy technologies. Data on household and industry sector electricity consumption was obtained from the IEA's Energy Balances Database (IEA 2006d).

Consistent with the 'induced innovation' hypothesis, the commercial viability of renewable energy is dependent in large part upon the its cost, relative to substitute factor inputs. Since the costs of electricity production using renewable energy sources are generally greater than for fossil fuels, an increase in the price of electricity should increase incentives for innovation in the area of renewable energies. Since renewable sources represent a relatively small proportion of total electricity generation, it is assumed that the price of electricity can be considered exogenous. Data on residential and industry end-user prices was obtained from IEA's Energy Prices and Taxes Database (IEA 2006e). The electricity price variable was constructed by weighting price indices for residential and industrial use by consumption levels. The sign is expected to be positive. 
Differences in both scientific capacity and the propensity to patent across countries and time are captured through the use of a variable which reflects overall EPO patent applications filed across the whole spectrum of technological areas (OECD 2007). In addition, inventors from non-European countries are less likely to patent at the EPO (home bias). This variable thus serves as a 'trend' variable in that it controls for the changes in general propensity to patent over time and across countries. The sign is expected to be positive. Table 4 provides basic descriptive statistics for the policy dummies and other explanatory variables.

\section{Model specification and empirical results}

\section{A. Model specification}

In order to test the hypotheses set out in Section 2 above, the following reduced-form equation is specified:

$$
\begin{aligned}
\left(\text { PATENTS }_{i, t}\right) & =\beta_{1}\left(\text { POLICY }_{i, t}\right)+\beta_{2}\left(R \& D_{i, t}\right)+\beta_{3}\left(\text { CONS }_{i, t}\right) \\
& +\beta_{4}\left(\text { PRICE }_{i, t}\right)+\beta_{5}\left(\text { EPO }_{i, t}\right)+\alpha_{i}+\varepsilon_{i, t}
\end{aligned}
$$

where $i=1, \ldots, 25$ indexes the cross-sectional unit (country) and $t=1978, \ldots, 2003$ indexes time. The dependent variable, patenting activity, is measured by the number of patent applications in each of the technological areas of renewable energy (wind, solar, geothermal, ocean, biomass, and waste). The explanatory variables include a vector of policy variables $\left(P O L I C Y_{i, t}\right)$, specific R\&D expenditures $\left(R \& D_{i, t}\right)$, electricity consumption $\left(C O N S_{i, t}\right)$, electricity price $\left(P R I C E_{i, t}\right)$ and total EPO filings $\left(E P O_{i, t}\right)$. Fixed effects $\left(\alpha_{i}\right)$ are introduced to capture unobservable country-specific heterogeneity. All the residual variation is captured by the error term $\left(\varepsilon_{i, t}\right)$.

A negative binomial model is used to estimate the equation in (1). Count data models, such as the Poisson and negative binomial, have been suggested for estimating the number of occurrences of an event, or event counts (Maddala 1983: 51; Cameron and Trivedi 1998). In this paper, an event count is the number of patent applications deposited at the EPO. Formally, an event count is defined as a realization of a nonnegative integer-valued random variable. We suppose that the number of 
patents $\left(\right.$ PATENTS $\left._{i, t}\right)$ follows a negative binomial distribution, i.e. the patent count is modeled as a Poisson process with an unobserved error parameter $(u)$ introducing heterogeneity in the variance, and an intensity parameter $(\mu)$ explained (in log) by a vector of explanatory variables $(X)$ :

$$
\begin{gathered}
\operatorname{PATENTS}_{i, t} \rightarrow \operatorname{NegBin}(\mu ; \sigma), \text { that is } \\
\operatorname{PATENTS~}_{i, t} \rightarrow \operatorname{Poisson}(\mu) \text { with }\left\{\begin{array}{c}
\mu=\tilde{\mu} \cdot u=\exp (\beta X) \\
u \rightarrow \Gamma\left(\frac{1}{\sigma} ; \frac{1}{\sigma}\right)
\end{array}\right.
\end{gathered}
$$

Therefore, $E\left(\right.$ PATENTS $\left._{i, t}\right)=\mu$ and $V($ PATENTS $)=\mu\left(1+\sigma^{2} \mu\right)$. It follows that as $\sigma^{2} \rightarrow 0$ the model converges to the Poisson distribution with intensity $\mu$. Maximum likelihood method is used to estimate the parameters. ${ }^{4}$

Using data on patent counts the determinants of patenting activity for renewable energy are assessed. In total, a panel of 25 countries and 26 years (1978-2003) is available, but the presence of missing observations and all-zero outcomes of patent count for some countries and some technologies reduce the size of the samples to between 400 and 500 in most models estimated. ${ }^{5}$

\section{B. Empirical results}

Several alternative specifications of the model were estimated. Table 5 presents the estimation results when all policy dummies are included in the regressions, except the dummy for R\&D programs (due to correlation with the intercept). ${ }^{6}$ The coefficient of electricity price has a positive sign in every

\footnotetext{
${ }^{4}$ For further details on negative binomial models, see Cameron and Trivedi (1998); Hausman, Hall and Griliches (1984).

${ }^{5}$ The variation in the number of observations used in the regression models is due (a) to a small number of missing values in the specific $R \& D$ variable, but (b) is mostly caused by all-zero outcomes of patent counts leading to data for individual countries being dropped from the regression.

${ }^{6}$ Most countries introduced R\&D support programs as early as the 1970s. Since our data begin in 1978, this policy variable is (almost perfectly) correlated with the intercept (fixed effects).
} 
equation. It is statistically significant at the $1 \%$ and $5 \%$ levels in the solar and biomass equations, respectively. This suggests that higher electricity prices provide an incentive for increased patenting activity in the solar and biomass technologies. The results also suggest that renewable-specific R\&D spending is a significant determinant of patenting in renewable energy overall, and especially in wind and ocean technologies. ${ }^{7}$ The estimated coefficient of electricity consumption is negative in every equation and statistically significant only in the waste-to-energy equation. One possible explanation of the negative sign could be related to the fact that policies aimed at renewables are often concurrent with policies aimed at encouraging energy efficiency. The estimated coefficient of the total number of EPO filings is positive and statistically significant at the $1 \%$ level in every technological area, suggesting that a part of the variation in patenting activity in renewable energies is due to changes in the general propensity to patent. ${ }^{8}$

The results on the policy dummies suggest that public policy plays a significant role in inducing innovations in renewable energies. However, the efficacy of alternative policy instruments in inducing innovations varies by renewable energy source. For wind technology and for renewable energies overall, tax measures, obligations, and tradable certificates are statistically significant (at the $5 \%$ level and higher) policy instruments. Given that wind power is currently the most cost-effective of these technologies, the finding that policies mandating additional renewable sources encourage innovation for wind, but not other renewables, is consistent with the notion that firms focus innovation on ways to comply with command and control regulations as cheaply as possible (Popp 2003). The variable reflecting the provision of investment incentives is statistically significant for

\footnotetext{
${ }^{7}$ The negative and significant coefficient in the biomass equation is counter-intuitive. It is possible that public R\&D is 'crowding out' private R\&D. However, why this should be the case specifically for biomass energy is not clear. Unfortunately, there is no data on private spending on $R \& D$ by renewable source, and as such this remains a conjecture. Note also that the coefficient is not statistically significant in any of the alternative models.

${ }^{8}$ The coefficient is insignificant in the ocean equation. This is most likely due to the low variation in ocean patent counts.
} 
innovations in solar power. This is consistent with the hypothesis that more direct incentives are needed for riskier investments. Investment incentives, as well as voluntary programs, are statistically significant policy instruments for waste-to-energy incineration. Finally, putting in place preferential tariff structures, and to a lesser extent tax measures, are statistically significant for patent activity with respect to biomass energy.

There are two concerns related to including all policy dummies in the regression. First, correlation among the dummies may cause multicollinearity problems. In particular, dummies representing investment incentives, tax measures, and tariffs are correlated (correlation coefficient 0.53 and 0.57$).{ }^{9}$ Similarly, obligations and tradable permits are correlated $(0.48) .{ }^{10}$ Second, it is possible that there are interaction effects among alternative policy instruments (e.g., investment incentives for capital goods may be accompanied by preferential tax rates for final goods). In an alternative specification, the individual policy dummies were included one-by-one in the regressions. The results (not reported) suggest that the key qualitative findings remain unaffected. Policies which are found to be statistically significant when all dummies are included in the regression remain statistically significant, and with the same signs, when they are included separately.

Including all policy dummies may cause multicollinearity. However, including policy dummies one-by-one may lead to incorrect conclusions due to omitted variables and possible interaction effects among the different policies. Two approaches are adopted in order to address these issues: (a) clusters of policy variables are developed by clustering similar policies in groups (to address possible multicollinearity and classification error); and (b) a composite policy variable is constructed using principal component analysis. This latter variable also allows assessing dynamic impacts in a more satisfactory manner.

\footnotetext{
${ }^{9}$ The negative and statistically significant coefficient of tariffs in the wind energy equation could be considered a consequence of multicollinearity. However, it remains robust even if the tax dummy is dropped.

${ }^{10}$ In spite of this, we get a positive and significant coefficient even for tradable certificates. This suggests that allowing obligations to be traded provides a strong incentive for innovation.
} 
Hierarchical cluster analysis is a method that can be applied in order to reduce a set of correlated variables into a smaller number of cluster components, with little loss of information. This allows for the identification of 'clusters' of policy instruments which are then used as explanatory variables. The variables are clustered in such a manner that variables within one group are correlated, but uncorrelated with variables in the other groups (see, for example, Hair et al. 1998).

The choice of the number of clusters to retain must be made ad hoc. We chose to use the clustering of policy variables which yields three conceptually distinct groups of policies: (1) pricebased policy instruments (including investment incentives, tax measures, and tariffs), (2) voluntary programs; and (3) quantity-based policy instruments (obligations and tradable certificates). We note that the dummy variable for voluntary programs is approximately equally correlated with the remaining two clusters. The estimated scoring coefficients were used to compute the component scores for each cluster.

Table 6 shows the regression estimates when policy variables are divided into three clusters. The estimated coefficients on the key regressors remain close to those obtained with individual policy variables. The results suggest that innovation effects of alternative policy instruments differ by the type of renewable energy technology. The evidence of differential policy effectiveness is particularly straightforward for wind, solar, biomass and waste-to-energy technologies. For wind power, the coefficient of quantity-based policy instruments (cluster 3) is positive and statistically significant at the $1 \%$ level, again supporting the notion that command and control first promotes innovation on the cheapest alternative. For solar, biomass and waste energy, the coefficients of price-based policy instruments (cluster 1) are positive and statistically significant at the $1 \%$ level. In addition, the coefficient of voluntary programs (cluster 2) in the waste equation is positive and statistically significant at the $5 \%$ level or higher. For ocean energy, none of the policy cluster variables are significant. Overall, for all renewables, the innovation effects of both price- and quantity-based instruments are highly statistically significant. Voluntary approaches seem to play a minor role.

As an alternative to cluster analysis, principal components analysis (PCA) was used to reduce the dimensionality of the set of individual policy variables. PCA transforms a number of correlated 
variables into a (smaller) number of uncorrelated variables (principal components). The first principal component accounts for as much of the variability in the data as possible, and in descending order each succeeding component accounts for as much of the remaining variability as possible (see, for example, Hair et al. 1998).

In this study, we chose to keep only the first principal component for two reasons: (a) it explains a good share of the variance (the inertia criterion), and (b) it is a true composite variable since all variables have a positive sign, while the second principal component opposes two clusters. In the first principal component, the estimated coefficients of all the policies are positive which means that the variable captures national tendencies to develop environmental policies to support renewable energy, but does not significantly disentangle policy types from each other. As a result, this variable does not help to draw conclusions on the efficacy of the different kinds of policies, but is a good indicator of the intensity of environmental regulation. The advantage of this approach is that the composite variable addresses the problem of multicollinearity, as well as potential interaction effects among policy instruments. Moreover, it can be lagged to analyze dynamic issues.

Table 7 presents the estimation results using the composite policy variable. The coefficients remain close to those obtained previously. The estimated coefficient of the composite policy variable is positive and statistically significant at the $5 \%$ level in every equation. This suggests that public policy is a significant driver of innovative activity in renewable energy overall, as well as for specific renewable energy sources. However, unlike before, we are unable to evaluate the effectiveness of various policy types using the composite variable.

Using the same model, the dynamic aspects of innovative activity were analyzed using 1 - to 4-year lags. In addition, for the composite policy variable a 1-year leap was tested since inventors may anticipate the introduction of policies in support of the use of renewable energy sources. The coefficients remain robust to such changes. The coefficient of the composite policy variable is most significant with lags between 0 and 2 years, suggesting that the impact of public policy on patenting is rather fast. This is consistent with the findings in Popp (2002) who found that energy patents followed energy price changes with little lag. 
Finally, there is a concern that variables such as electricity consumption, EPO patent filings, and fixed effects may all, to a certain extent, reflect the same national tendencies. Including all of these variables in a regression may cause 'over-fitting' of the model. However, when country-specific fixed effects are dropped from the regression the key qualitative findings remain robust.

In sum, the variable (EPO filings) reflecting scientific capacity and general propensity to patent is consistently positive and significant. However, electricity price is only significant and positive for solar power and electricity consumption is generally insignificant. Overall, public policy plays an important role. Public expenditures on renewable-specific R\&D consistently have a positive and significant effect on patent activity, particularly for wind and ocean energy.

The other major policy-related finding of this paper is that different policies have a greater effect on patent activity for some renewable energy sources than for others. In particular, quantitybased policy instruments such as obligations and tradable certificates are most effective in inducing innovations in wind power technology. Price-based instruments such as investment incentives, tax measures and tariffs are most effective in encouraging innovation in solar, biomass, and waste-toenergy technologies. Voluntary programs are not significant, except perhaps in the case of waste. These findings are robust to alternative policy measures and model specifications. ${ }^{11}$

While our policy choice hypotheses are not fully supported, there are good economic reasons to explain some of the findings. For instance, the significance of investment incentives for solar energy is likely due to the fact that many solar installations are the most capital intensive (in terms of investment costs required per $\mathrm{kW}$ ) among the studied renewable energy technologies (see, for example, Dickson and Fanelli 2004). Waste-to-energy investments can also involve significant upfront fixed costs, and the coefficient is significant and positive in this case as well. In addition, the relative importance of voluntary programs for waste may be explained by the importance of the public sector in waste management, perhaps obviating the need for mandatory regulations. The hypothesis

\footnotetext{
${ }^{11}$ In addition to the models described above, random effects negative binomial models were estimated and the results confirm robustness of the major findings.
} 
that quantity-based measures are likely to be more important for less mature technologies (that is, that such policies can be "technology forcing") is not supported. Indeed, it is only in the case of wind power that obligations are significant. However, the significant and positive coefficient on price-based measures (feed-in tariffs) for biomass is consistent with our hypothesis since this source is relatively mature and competitive.

\section{Conclusions}

This paper examines the effects of public policies on innovation in the area of renewable energies in a cross-section of OECD countries over the period 1978-2003. Patent counts are used as the most suitable proxy for innovation and the effects of a wide variety of different policy types are assessed.

The descriptive data indicates rapid growth in wind and waste-to-energy patent activity, particularly since the mid-1990s. There continues to be innovation with respect to solar energy, perhaps reflecting the opportunities presented by developments in concentrating solar power. Innovation with respect to biomass and ocean energy are also growing, but from a very low base. And finally, there appears to have been little innovation in the area of geothermal energy since the 1970s.

At the same time, significant changes have occurred in the public policy framework put in place to support renewable energy. Initially $R \& D$ programs were introduced in a number of countries. This was followed by investment incentives, and later, tax incentives and preferential tariffs. Next, voluntary programs were developed. More recently, quantitative obligations, and finally tradable certificates, have been applied.

Our empirical results indicate that public policy has had a very significant influence on the development of new technologies in the area of renewable energy. Using the composite policy variable, statistical significance at the $1 \%$ level is found for all renewable energy sources, except biomass (where it is significant at the 5\% level). However, the results suggest that instrument choice also matters. With respect to patent activity in renewable energy overall, taxes, obligations and tradable certificates are the only statistically significant policy instruments. 
Interestingly however, source-specific models indicate that there is variation in the effects of instrument type on different renewables. As governments place increasing emphasis on developing a portfolio of energy alternatives, understanding these differences is important for policy. Broadly, investment incentives are effective in supporting innovation in solar and waste-to-energy technologies, tariff structures are important for biomass, obligations and tradable certificates (which are closely related) support wind technology, and voluntary programs are helpful in inducing wasteto-energy innovations. Overall, only tax incentives have wide influence on innovation for a number of renewable energy sources.

While the results are interesting and robust, further work in the area could be undertaken. This includes accounting for variation in natural conditions as determinants of patenting in renewable energy technologies, and better examination of dynamic issues, with a particular focus on addressing the possible simultaneity of R\&D expenditures and patenting activity. 


\section{References}

Binswanger H (1974) A microeconomic approach to induced innovation. The Economic Journal 84: 940-958.

Brunnermeier SB, Cohen MA (2003) Determinants of environmental innovation in US manufacturing industries. J. Environ. Econom. Management 45: 278-293.

Cameron AC, Trivedi PK (1998) Regression analysis of count data. Cambridge University Press, Cambridge; New York.

De Vries FP, Withagen C (2005) Innovation and environmental stringency: the case of sulfur dioxide abatement. CentER Discussion Paper \#2005-18, Tilburg University, The Netherlands.

Dernis H, Guellec D (2001) Using patent counts for cross-country comparisons of technology output. STI mimeo, Organisation for Economic Co-operation and Development, Paris, France (http://www.oecd.org/dataoecd/26/11/21682515.pdf).

Dernis H, Kahn M (2004) Triadic patent families methodology. STI working paper 2004/2, Organisation for Economic Co-operation and Development, Paris, France.

Dickson MH, Fanelli M (2004) What is geothermal energy? Instituto di Geoscienze e Georisorse, CNR, Pisa, Italy.

Griliches Z (1990) Patent statistics as economic indicators: a survey. Journal of Economic Literature 28(4): 1661-1707.

Hair, Jr., JF, Anderson RE, Tatham RL, Black WC (1998) Multivariate data analysis. 5th edition. Prentice Hall, Upper Saddle River, New Jersey, USA.

Hausman J, Hall BH, Griliches Z (1984) Econometric models for count data with an application to the patents-R\&D relationship. Econometrica 52: 909-938.

International Energy Agency (2004) Renewable energy - market and policy trends in IEA countries. IEA, Paris, France. 
International Energy Agency (2006a) Renewable energy: RD\&D priorities, insights from the IEA technology programmes. IEA, Paris, France.

International Energy Agency (2006b) Renewables information: 2006. IEA, Paris, France.

International Energy Agency (2006c) Energy technology research and development database. IEA, Paris, France (http://data.iea.org).

International Energy Agency (2006d) Energy balances of OECD countries. IEA, Paris, France (http://data.iea.org).

International Energy Agency (2006e) Energy prices and taxes. IEA, Paris, France (http://data.iea.org).

International Energy Agency (2007) Global renewable energy policies and measures database. IEA, Paris, France (http://www.iea.org/textbase/pamsdb/grindex.aspx).

Jaffe AB, Newell R, Stavins RN (2002) Technological change and the environment. Environmental and Resources Economics 22: 41-69.

Jaffe AB, Palmer K (1997) Environmental regulation and innovation: a panel data study. Review of Economics and Statistics 79(4): 610-619.

Jaumotte F, Pain N (2005) From ideas to development: the determinants of R\&D and patenting. OECD Economics Department Working Paper \#457, ECO/WKP(2005)44.

Lanjouw JO, Mody A (1996) Innovation and the international diffusion of environmentally responsive technology. Research Policy 25: 549-571.

Maddala GS (1983) Limited-dependent and qualitative variables in econometrics. Cambridge University Press, Cambridge, U.K.

Morgenstern R, Pizer W (2007) Reality check: the nature and performance of voluntary environmental programs in the United States, Europe, and Japan. RFF Press, Washington D.C.

Organisation for Economic Co-operation and Development (2007) OECD Patent Database. OECD, Paris, France. 
Popp D (2002) Induced innovation and energy prices. The American Economic Review 92(1): 160180.

Popp D (2003) Pollution control innovations and the Clean Air Act of 1990. Journal of Policy Analysis and Management 22(4): 641-660.

Popp D (2005) Using the Triadic Patent Family Database to study environmental innovation. OECD Environment Directorate Working Paper ENV/EPOC/WPNEP/RD(2005)2, OECD, Paris, France.

Popp D (2006) International innovation and diffusion of air pollution control technologies: the effects of $\mathrm{NO}_{\mathrm{X}}$ and $\mathrm{SO}_{2}$ regulation in the U.S., Japan, and Germany. Journal of Environmental Economics and Management 51: 46-71.

Scherer FM (1982) Demand-pull and technological invention: Schmookler revisited. Journal of Industrial Economics 30: 225-237.

Scherer FM, Harhoff D (2000) Technology policy for a world of skew-distributed outcomes. Research Policy 29: 559-566.

Schmookler J (1966) Invention and economic growth. Harvard University Press, Cambridge.

United States Department of Energy (2007) Energy efficiency and renewable energy. News release on January 4, 2007. (http://www.eere.energy.gov/buildings/news_detail.html/news_id=10489). 
Table 1. International patent classification (IPC) system

\begin{tabular}{|c|c|c|c|}
\hline Subdivision & $\begin{array}{c}\text { Number of } \\
\text { subdivisions }\end{array}$ & \multicolumn{2}{|c|}{ Example of an IPC code } \\
\cline { 3 - 4 } Section & 8 & F & $\begin{array}{c}\text { Mechanical Engineering; Lighting; Heating; } \\
\text { Weapons; Blasting }\end{array}$ \\
\hline \hline Subsection & 21 & F0 & Engines or Pumps \\
\hline Class & 120 & F03 & $\begin{array}{c}\text { Machines or Engines for Liquids; Wind, Spring, } \\
\text { or Weight Motors; Producing Mechanical Power } \\
\text { or a Reactive Propulsive Thrust, Not Otherwise } \\
\text { Subclass }\end{array}$ \\
& 628 & F03G & $\begin{array}{c}\text { Spring, Weight, Inertia, or Like Motors; } \\
\text { Mechanical-Power-Producing Devices or } \\
\text { Mechanisms, Not Otherwise Provided For; or } \\
\text { Using Energy Sources Not Otherwise Provided } \\
\text { For }\end{array}$ \\
\hline Main group & ca. 6,900 & F03G 6 & $\begin{array}{c}\text { Devices For Producing Mechanical Power From } \\
\text { Solar Energy... }\end{array}$ \\
\hline Subgroup & ca. 62,100 & F03G 6/08 & With Solar Energy Concentrating Means \\
\hline
\end{tabular}


Table 2. Number of EPO Patent Applications in Renewable Energy Technologies per Unit of GDP (1978-2003)

\begin{tabular}{|c|c|c|c|c|c|c|c|c|}
\hline & Wind & Solar & $\begin{array}{c}\text { Geo- } \\
\text { thermal }\end{array}$ & Ocean & Biomass & Waste & $\begin{array}{c}\text { All } \\
\text { renewables }\end{array}$ & $\begin{array}{c}1978-2003 \\
\text { Total }\end{array}$ \\
\hline AT & 2.54 & 6.55 & 6.76 & 0.85 & 1.48 & 5.07 & 23.24 & 110 \\
\hline $\mathrm{AU}$ & 0.49 & 4.82 & 1.08 & 0.49 & 0.29 & 1.08 & 8.26 & 84 \\
\hline BE & 4.17 & 2.26 & 1.91 & 0.17 & 0.70 & 1.39 & 10.60 & 59 \\
\hline CA & 0.88 & 0.82 & 0.35 & 0.12 & 0.18 & 1.76 & 4.05 & 66 \\
\hline $\mathrm{CH}$ & 2.66 & 11.07 & 6.97 & 0.41 & 0.82 & 6.97 & 28.90 & 138 \\
\hline $\mathrm{DE}$ & 8.14 & 7.51 & 4.10 & 0.41 & 2.07 & 6.90 & 28.99 & 1285 \\
\hline DK & 27.16 & 3.70 & 1.54 & 3.40 & 1.23 & 5.86 & 42.91 & 137 \\
\hline ES & 1.49 & 1.25 & 0.12 & 0.71 & 0.00 & 0.12 & 3.69 & 61 \\
\hline FI & 2.55 & 3.27 & 1.09 & 0.73 & 0.00 & 4.73 & 12.37 & 34 \\
\hline FR & 1.42 & 1.51 & 2.23 & 0.27 & 1.27 & 1.48 & 8.15 & 267 \\
\hline GB & 1.65 & 1.10 & 0.78 & 0.81 & 4.59 & 1.62 & 10.41 & 322 \\
\hline GR & 1.27 & 1.27 & 0.00 & 0.51 & 0.00 & 0.51 & 3.55 & 14 \\
\hline HU & 0.68 & 1.71 & 1.71 & 0.68 & 0.34 & 0.00 & 5.13 & 15 \\
\hline IE & 2.95 & 2.36 & 0.00 & 2.95 & 0.00 & 0.00 & 8.27 & 14 \\
\hline IT & 0.97 & 1.10 & 0.75 & 0.50 & 0.25 & 1.06 & 4.63 & 148 \\
\hline JP & 0.64 & 2.68 & 0.64 & 0.16 & 0.29 & 5.00 & 9.41 & 656 \\
\hline KR & 0.66 & 0.08 & 0.00 & 0.08 & 0.08 & 0.33 & 1.23 & 15 \\
\hline NL & 5.74 & 4.53 & 2.76 & 0.55 & 0.99 & 3.42 & 17.78 & 161 \\
\hline NO & 2.51 & 2.20 & 1.57 & 3.76 & 0.31 & 0.94 & 11.29 & 36 \\
\hline $\mathrm{NZ}$ & 0.59 & 0.00 & 0.59 & 0.59 & 0.59 & 1.77 & 4.13 & 7 \\
\hline PL & 0.11 & 0.23 & 0.23 & 0.00 & 0.11 & 0.11 & 0.80 & 7 \\
\hline PT & 1.37 & 1.37 & 0.00 & 0.27 & 0.00 & 0.27 & 3.29 & 12 \\
\hline SE & 6.86 & 3.14 & 5.69 & 3.14 & 0.78 & 2.16 & 21.76 & 109 \\
\hline TW & 0.70 & 0.56 & 0.14 & 0.14 & 0.00 & 0.70 & 2.25 & 16 \\
\hline US & 0.52 & 0.81 & 0.51 & 0.28 & 1.19 & 1.60 & 4.92 & 925 \\
\hline Total & 942 & 1079 & 616 & 216 & 566 & 1285 & 4702 & \\
\hline
\end{tabular}

Note: The table gives the annual mean number of patent applications for renewables during 19782003, classified by inventor country, and normalized by country's GDP (in trillions of US dollars, using 2000 prices and PPP). Countries in the top five for each renewable are indicated in bold face. 
Table 3. Number of EPO Patent Applications in Renewable Energy Technologies, Normalized by Overall Patenting Activity (1978-2003)

\begin{tabular}{lrrrrrrr}
\hline & Wind & Solar & $\begin{array}{c}\text { Geo- } \\
\text { thermal }\end{array}$ & Ocean & Biomass & Waste & $\begin{array}{c}\text { All } \\
\text { renewables }\end{array}$ \\
\hline AT & 0.67 & $\mathbf{1 . 7 5}$ & $\mathbf{1 . 7 6}$ & 0.22 & $\mathbf{0 . 3 9}$ & $\mathbf{1 . 3 3}$ & $\mathbf{6 . 1 3}$ \\
AU & 0.39 & $\mathbf{3 . 7 5}$ & $\mathbf{0 . 8 6}$ & $\mathbf{0 . 4 2}$ & 0.25 & 0.84 & $\mathbf{6 . 5 0}$ \\
BE & $\mathbf{1 . 3 1}$ & 0.69 & 0.61 & 0.06 & 0.17 & 0.44 & 3.28 \\
CA & 0.73 & 0.68 & 0.30 & 0.08 & 0.16 & $\mathbf{1 . 3 8}$ & 3.34 \\
CH & 0.29 & 1.15 & $\mathbf{0 . 7 5}$ & 0.03 & 0.08 & 0.74 & 3.03 \\
DE & 1.10 & 1.01 & 0.55 & 0.05 & 0.27 & 0.93 & 3.91 \\
DK & $\mathbf{7 . 6 5}$ & 1.03 & 0.44 & $\mathbf{0 . 9 2}$ & $\mathbf{0 . 3 5}$ & $\mathbf{1 . 6 4}$ & $\mathbf{1 2 . 0 4}$ \\
ES & $\mathbf{2 . 6 2}$ & $\mathbf{2 . 2 9}$ & 0.24 & $\mathbf{1 . 3 1}$ & 0.00 & 0.24 & $\mathbf{6 . 7 0}$ \\
FI & 0.47 & 0.60 & 0.20 & 0.13 & 0.00 & 0.85 & 2.25 \\
FR & 0.37 & 0.39 & 0.60 & 0.07 & $\mathbf{0 . 3 3}$ & 0.39 & 2.15 \\
GB & 0.51 & 0.35 & 0.24 & 0.25 & $\mathbf{1 . 4 6}$ & 0.50 & 3.32 \\
IT & 0.53 & 0.61 & 0.42 & 0.28 & 0.14 & 0.59 & 2.57 \\
JP & 0.16 & 0.65 & 0.16 & 0.04 & 0.07 & $\mathbf{1 . 2 1}$ & 2.29 \\
KR & 0.62 & 0.08 & 0.00 & 0.08 & 0.08 & 0.31 & 1.16 \\
NL & 1.11 & 0.88 & 0.55 & 0.10 & 0.20 & 0.68 & 3.52 \\
NO & $\mathbf{1 . 6 8}$ & $\mathbf{1 . 4 1}$ & $\mathbf{1 . 0 1}$ & $\mathbf{2 . 3 9}$ & 0.20 & 0.61 & $\mathbf{7 . 3 1}$ \\
SE & 1.05 & 0.49 & $\mathbf{0 . 9 0}$ & $\mathbf{0 . 4 9}$ & 0.11 & 0.31 & 3.36 \\
TW & $\mathbf{1 . 4 8}$ & $\mathbf{1 . 1 9}$ & 0.30 & 0.30 & 0.00 & $\mathbf{1 . 4 8}$ & 4.75 \\
US & 0.21 & 0.33 & 0.21 & 0.11 & $\mathbf{0 . 4 8}$ & 0.66 & 2.01 \\
\hline
\end{tabular}

Note: The table gives the total number of patent applications for renewables during 1978-2003,

classified by inventor country, and normalized by country's total number of patent applications in all technology areas (in millions of EPO filings). Only countries with a minimum of 2,600 EPO patent filings overall $\left(25^{\text {th }}\right.$ percentile $)$ are included in the table. Countries in the top five for each renewable are indicated in bold face. 
Table 4. Descriptive statistics of explanatory variables (1978-2003)

\begin{tabular}{lccc}
\hline Variable & Obs. & Mean & Std. Dev. \\
\hline Policy dummies & 676 & 0.8432 & 0.3639 \\
R\&D support & 676 & 0.4127 & 0.4927 \\
Investment incentives & 676 & 0.2722 & 0.4454 \\
Tax measures & 676 & 0.3151 & 0.4649 \\
Tariffs & 676 & 0.1050 & 0.3068 \\
Voluntary programs & 676 & 0.2130 & 0.4097 \\
Obligations & 676 & 0.0577 & 0.2333 \\
Tradable certificates & \multicolumn{3}{c}{} \\
& & \\
Technology-specific R\&D expenditures (10e9 USD, 2005 prices and PPP) & \\
Wind R\&D & 478 & 0.0063 & 0.0140 \\
Solar R\&D & 479 & 0.0237 & 0.0702 \\
Ocean R\&D & 477 & 0.0016 & 0.0077 \\
Bioenergy R\&D & 478 & 0.0086 & 0.0157 \\
Renewables R\&D & 482 & 0.0481 & 0.1261 \\
& \multicolumn{3}{|c}{} \\
Electricity price (US\$/unit, using PPP) & 583 & 0.0849 & 0.0345 \\
Electricity consumption (millions GWh) & 624 & 0.0158 & 0.0323 \\
Total EPO patent filings (thousands) & 673 & 2.3964 & 4.9912 \\
\hline
\end{tabular}


Table 5. Estimated coefficients of the negative binomial fixed effects models with individual policy variables

\begin{tabular}{|c|c|c|c|c|c|c|}
\hline & Wind & Solar & Ocean & Biomass & Waste & All renewables \\
\hline Electricity price & $\begin{array}{c}3.187 \\
(0.488)\end{array}$ & $\begin{array}{c}18.718^{* * *} \\
(0.000)\end{array}$ & $\begin{array}{c}2.181 \\
(0.737)\end{array}$ & $\begin{array}{l}14.769^{*} \\
(0.035)\end{array}$ & $\begin{array}{c}2.957 \\
(0.469)\end{array}$ & $\begin{array}{c}0.994 \\
(0.683)\end{array}$ \\
\hline $\begin{array}{l}\text { Specific R\&D } \\
\text { expenditures }\end{array}$ & $\begin{array}{c}17.789^{* * *} \\
(0.000)\end{array}$ & $\begin{array}{c}0.966 \\
(0.153)\end{array}$ & $\begin{array}{l}13.889^{*} \\
(0.038)\end{array}$ & $\begin{array}{l}-7.473^{*} \\
(0.043)\end{array}$ & $\begin{array}{c}0.479 \\
(0.249)\end{array}$ & $\begin{array}{l}1.063^{* *} \\
(0.000)\end{array}$ \\
\hline $\begin{array}{l}\text { Electricity } \\
\text { consumption }\end{array}$ & $\begin{array}{l}-9.630 \\
(0.123)\end{array}$ & $\begin{array}{l}-8.060 \\
(0.141)\end{array}$ & $\begin{array}{c}-15.200 \\
(0.335)\end{array}$ & $\begin{array}{c}-15.900 \\
(0.115)\end{array}$ & $\begin{array}{c}-13.600^{* *} \\
(0.005)\end{array}$ & $\begin{array}{l}-5.030 \\
(0.162)\end{array}$ \\
\hline Total EPO filings & $\begin{array}{l}0.106^{* *} \\
(0.001)\end{array}$ & $\begin{array}{l}0.074^{* *} \\
(0.000)\end{array}$ & $\begin{array}{c}0.069 \\
(0.188)\end{array}$ & $\begin{array}{l}0.121^{* *} \\
(0.001)\end{array}$ & $\begin{array}{l}0.122^{* *} \\
(0.000)\end{array}$ & $\begin{array}{l}0.081^{* *} \\
(0.000)\end{array}$ \\
\hline \multicolumn{7}{|l|}{ Policy dummies } \\
\hline $\begin{array}{l}\text { Investment } \\
\text { incentives }\end{array}$ & $\begin{array}{l}-0.214 \\
(0.292)\end{array}$ & $\begin{array}{l}0.626^{* *} \\
(0.000)\end{array}$ & $\begin{array}{l}-0.097 \\
(0.740)\end{array}$ & $\begin{array}{l}-0.176 \\
(0.481)\end{array}$ & $\begin{array}{l}0.723^{* *} \\
(0.000)\end{array}$ & $\begin{array}{c}0.145 \\
(0.146)\end{array}$ \\
\hline Tax measures & $\begin{array}{c}0.371^{*} \\
(0.040)\end{array}$ & $\begin{array}{c}-0.021 \\
(0.881)\end{array}$ & $\begin{array}{c}0.538 \\
(0.089)\end{array}$ & $\begin{array}{c}0.500^{*} \\
(0.050)\end{array}$ & $\begin{array}{c}0.083 \\
(0.578)\end{array}$ & $\begin{array}{c}0.235^{*} \\
(0.017)\end{array}$ \\
\hline Tariffs & $\begin{array}{l}-0.434 \\
(0.053)\end{array}$ & $\begin{array}{c}0.116 \\
(0.547)\end{array}$ & $\begin{array}{c}0.015 \\
(0.964)\end{array}$ & $\begin{array}{l}0.783^{* *} \\
(0.000)\end{array}$ & $\begin{array}{c}0.192 \\
(0.336)\end{array}$ & $\begin{array}{l}-0.043 \\
(0.717)\end{array}$ \\
\hline $\begin{array}{l}\text { Voluntary } \\
\text { programs }\end{array}$ & $\begin{array}{c}0.089 \\
(0.718)\end{array}$ & $\begin{array}{c}0.020 \\
(0.898)\end{array}$ & $\begin{array}{l}-0.066 \\
(0.863)\end{array}$ & $\begin{array}{l}-0.240 \\
(0.307)\end{array}$ & $\begin{array}{c}0.334^{*} \\
(0.043)\end{array}$ & $\begin{array}{c}0.119 \\
(0.318)\end{array}$ \\
\hline Obligations & $\begin{array}{l}1.157^{* *} \\
(0.000)\end{array}$ & $\begin{array}{c}0.181 \\
(0.214)\end{array}$ & $\begin{array}{c}0.472 \\
(0.155)\end{array}$ & $\begin{array}{l}-0.212 \\
(0.372)\end{array}$ & $\begin{array}{c}0.045 \\
(0.761)\end{array}$ & $\begin{array}{l}0.384^{* *} \\
(0.001)\end{array}$ \\
\hline $\begin{array}{l}\text { Tradable } \\
\text { certificates }\end{array}$ & $\begin{array}{c}0.485^{*} \\
(0.034)\end{array}$ & $\begin{array}{c}0.064 \\
(0.718)\end{array}$ & $\begin{array}{c}0.192 \\
(0.597)\end{array}$ & $\begin{array}{l}-0.081 \\
(0.798)\end{array}$ & $\begin{array}{c}0.245 \\
(0.159)\end{array}$ & $\begin{array}{c}0.305^{*} \\
(0.016)\end{array}$ \\
\hline Intercept & $\begin{array}{l}-0.214 \\
(0.598)\end{array}$ & $\begin{array}{c}0.267 \\
(0.685)\end{array}$ & $\begin{array}{l}15.394 \\
(0.992)\end{array}$ & $\begin{array}{c}1.012 \\
(0.371)\end{array}$ & $\begin{array}{c}0.372 \\
(0.509)\end{array}$ & $\begin{array}{l}0.995^{* *} \\
(0.000)\end{array}$ \\
\hline $\begin{array}{l}\text { Observations } \\
\text { Log-likelihood } \\
\text { Wald chi } 2 \\
(\text { Prob > chi2) }\end{array}$ & $\begin{array}{c}452 \\
-477.65 \\
250.63 \\
(0.000) \\
\end{array}$ & $\begin{array}{c}427 \\
-488.20 \\
209.21 \\
(0.000) \\
\end{array}$ & $\begin{array}{c}450 \\
-238.56 \\
33.22 \\
(0.000) \\
\end{array}$ & $\begin{array}{c}334 \\
-289.98 \\
80.03 \\
(0.000) \\
\end{array}$ & $\begin{array}{c}441 \\
-482.30 \\
337.01 \\
(0.000) \\
\end{array}$ & $\begin{array}{c}463 \\
-926.40 \\
398.90 \\
(0.000) \\
\end{array}$ \\
\hline
\end{tabular}

Notes: * and ** refer to $5 \%$ and $1 \%$ level of statistical significance. P-values are in parentheses. The dependent variable is the patent count (successful and unsuccessful applications) in a given technological area. Intercept represents the average value of the country-specific fixed effects. Results for geothermal energy are not reported because they represent a significant outlier. 
Table 6. Estimated coefficients of the negative binomial fixed effects models

with clusters of policy variables

\begin{tabular}{|c|c|c|c|c|c|c|}
\hline & Wind & Solar & Ocean & Biomass & Waste & $\begin{array}{c}\text { All } \\
\text { renewables }\end{array}$ \\
\hline Electricity price & $\begin{array}{l}-2.465 \\
(0.547)\end{array}$ & $\begin{array}{c}20.112^{* *} \\
(0.000)\end{array}$ & $\begin{array}{c}1.787 \\
(0.775)\end{array}$ & $\begin{array}{l}12.459 \\
(0.094)\end{array}$ & $\begin{array}{l}5.013 \\
(0.190)\end{array}$ & $\begin{array}{c}0.094 \\
(0.968)\end{array}$ \\
\hline $\begin{array}{r}\text { Specific R\&D } \\
\text { expenditures }\end{array}$ & $\begin{array}{c}16.944^{* *} \\
(0.000)\end{array}$ & $\begin{array}{c}1.100 \\
(0.091)\end{array}$ & $\begin{array}{l}15.028^{*} \\
(0.023)\end{array}$ & $\begin{array}{l}-6.705 \\
(0.067)\end{array}$ & $\begin{array}{c}0.490 \\
(0.245)\end{array}$ & $\begin{array}{l}1.069^{* *} \\
(0.000)\end{array}$ \\
\hline $\begin{array}{l}\text { Electricity } \\
\text { consumption }\end{array}$ & $\begin{array}{l}-11.551 \\
(0.073)\end{array}$ & $\begin{array}{l}-7.088 \\
(0.175)\end{array}$ & $\begin{array}{l}-13.868 \\
(0.361)\end{array}$ & $\begin{array}{l}-9.658 \\
(0.253)\end{array}$ & $\begin{array}{c}-11.160^{*} \\
(0.011)\end{array}$ & $\begin{array}{l}-5.825 \\
(0.109)\end{array}$ \\
\hline Total EPO filings & $\begin{array}{l}0.121^{* *} \\
(0.000)\end{array}$ & $\begin{array}{l}0.075^{* *} \\
(0.000)\end{array}$ & $\begin{array}{c}0.064 \\
(0.199)\end{array}$ & $\begin{array}{l}0.094^{* *} \\
(0.004)\end{array}$ & $\begin{array}{l}0.116^{* *} \\
(0.000)\end{array}$ & $\begin{array}{l}0.087^{* *} \\
(0.000)\end{array}$ \\
\hline \multicolumn{7}{|l|}{ Policy clusters } \\
\hline $\begin{array}{l}\text { Policy cluster } 1 \\
\text { (incl. inv, tax, tar) }\end{array}$ & $\begin{array}{l}-0.018 \\
(0.941)\end{array}$ & $\begin{array}{l}0.614^{* *} \\
(0.000)\end{array}$ & $\begin{array}{c}0.419 \\
(0.216)\end{array}$ & $\begin{array}{l}1.053^{* *} \\
(0.000)\end{array}$ & $\begin{array}{l}0.728^{* *} \\
(0.000)\end{array}$ & $\begin{array}{l}0.310^{* *} \\
(0.005)\end{array}$ \\
\hline $\begin{array}{l}\text { Policy cluster } 2 \\
\text { (incl. vol) }\end{array}$ & $\begin{array}{l}-0.006 \\
(0.980)\end{array}$ & $\begin{array}{c}0.030 \\
(0.843)\end{array}$ & $\begin{array}{l}-0.075 \\
(0.842)\end{array}$ & $\begin{array}{l}-0.127 \\
(0.573)\end{array}$ & $\begin{array}{c}0.366^{*} \\
(0.031)\end{array}$ & $\begin{array}{c}0.072 \\
(0.521)\end{array}$ \\
\hline $\begin{array}{l}\text { Policy cluster } 3 \\
\text { (incl. oblig, trad) }\end{array}$ & $\begin{array}{l}1.632^{* *} \\
(0.000)\end{array}$ & $\begin{array}{c}0.209 \\
(0.184)\end{array}$ & $\begin{array}{c}0.665 \\
(0.055)\end{array}$ & $\begin{array}{l}-0.508 \\
(0.074)\end{array}$ & $\begin{array}{c}0.219 \\
(0.184)\end{array}$ & $\begin{array}{l}0.639^{* *} \\
(0.000)\end{array}$ \\
\hline Intercept & $\begin{array}{l}-0.132 \\
(0.726)\end{array}$ & $\begin{array}{c}0.006 \\
(0.991)\end{array}$ & $\begin{array}{l}13.727 \\
(0.982)\end{array}$ & $\begin{array}{c}0.346 \\
(0.646)\end{array}$ & $\begin{array}{l}-0.027 \\
(0.955)\end{array}$ & $\begin{array}{l}1.029^{* *} \\
(0.000)\end{array}$ \\
\hline $\begin{array}{l}\text { Observations } \\
\text { Log-likelihood } \\
\text { Wald chi2 } \\
(\text { Prob > chi2) }\end{array}$ & $\begin{array}{c}452 \\
-483.95 \\
216.29 \\
(0.000) \\
\end{array}$ & $\begin{array}{c}427 \\
-493.77 \\
200.81 \\
(0.000) \\
\end{array}$ & $\begin{array}{r}450 \\
-239.69 \\
31.89 \\
(0.000) \\
\end{array}$ & $\begin{array}{r}334 \\
-293.72 \\
64.08 \\
(0.000) \\
\end{array}$ & $\begin{array}{c}441 \\
-487.22 \\
297.49 \\
(0.000) \\
\end{array}$ & $\begin{array}{c}463 \\
-927.89 \\
393.14 \\
(0.000) \\
\end{array}$ \\
\hline
\end{tabular}

Notes: * and ** refer to $5 \%$, and $1 \%$ level of statistical significance. P-values are in parentheses. The dependent variable is the patent count (successful and unsuccessful applications) in a given technological area. The coefficient on the intercept represents the average value of the countryspecific fixed effects. Policy cluster 1 includes investment incentives, tax measures, and tariffs; Policy cluster 2 includes voluntary programs; Policy cluster 3 includes obligations and tradable certificates. 
Table 7. Estimated coefficients of the negative binomial fixed effects models with a composite policy variable

\begin{tabular}{|c|c|c|c|c|c|c|}
\hline & Wind & Solar & Ocean & Biomass & Waste & $\begin{array}{c}\text { All } \\
\text { renewables }\end{array}$ \\
\hline Electricity price & $\begin{array}{l}-4.679 \\
(0.265)\end{array}$ & $\begin{array}{c}19.671^{* *} \\
(0.000)\end{array}$ & $\begin{array}{c}1.442 \\
(0.818)\end{array}$ & $\begin{array}{l}12.337 \\
(0.080)\end{array}$ & $\begin{array}{c}4.813 \\
(0.210)\end{array}$ & $\begin{array}{c}0.110 \\
(0.963)\end{array}$ \\
\hline $\begin{array}{r}\text { Specific R\&D } \\
\text { expenditures }\end{array}$ & $\begin{array}{c}15.024^{* * *} \\
(0.000)\end{array}$ & $\begin{array}{c}0.956 \\
(0.155)\end{array}$ & $\begin{array}{l}13.824^{*} \\
(0.029)\end{array}$ & $\begin{array}{l}-7.415 \\
(0.057)\end{array}$ & $\begin{array}{c}0.483 \\
(0.257)\end{array}$ & $\begin{array}{l}1.088^{* * *} \\
(0.000)\end{array}$ \\
\hline $\begin{array}{l}\text { Electricity } \\
\text { consumption }\end{array}$ & $\begin{array}{c}-15.010^{* *} \\
(0.006)\end{array}$ & $\begin{array}{l}-6.070 \\
(0.210)\end{array}$ & $\begin{array}{l}-17.008 \\
(0.249)\end{array}$ & $\begin{array}{l}-0.918 \\
(0.894)\end{array}$ & $\begin{array}{l}-9.462^{*} \\
(0.024)\end{array}$ & $\begin{array}{l}-7.669^{*} \\
(0.021)\end{array}$ \\
\hline Total EPO filings & $\begin{array}{l}0.106^{* *} \\
(0.000)\end{array}$ & $\begin{array}{l}0.064^{* *} \\
(0.000)\end{array}$ & $\begin{array}{c}0.055 \\
(0.251)\end{array}$ & $\begin{array}{c}0.063^{*} \\
(0.025)\end{array}$ & $\begin{array}{l}0.117^{* *} \\
(0.000)\end{array}$ & $\begin{array}{l}0.087^{* * *} \\
(0.000)\end{array}$ \\
\hline $\begin{array}{l}\text { Composite } \\
\text { policy variable }\end{array}$ & $\begin{array}{l}0.366^{* *} \\
(0.000)\end{array}$ & $\begin{array}{l}0.162^{* *} \\
(0.000)\end{array}$ & $\begin{array}{l}0.226^{* *} \\
(0.000)\end{array}$ & $\begin{array}{l}0.097^{*} \\
(0.047)\end{array}$ & $\begin{array}{l}0.223^{* *} \\
(0.000)\end{array}$ & $\begin{array}{l}0.202^{* *} \\
(0.000)\end{array}$ \\
\hline Intercept & $\begin{array}{c}0.168 \\
(0.660)\end{array}$ & $\begin{array}{c}0.275 \\
(0.617)\end{array}$ & $\begin{array}{l}17.660 \\
(0.968)\end{array}$ & $\begin{array}{l}0.276 \\
(0.675)\end{array}$ & $\begin{array}{c}0.251 \\
(0.595)\end{array}$ & $\begin{array}{l}1.284^{* *} \\
(0.000)\end{array}$ \\
\hline $\begin{array}{l}\text { Observations } \\
\text { Log-likelihood } \\
\text { Wald chi2 } \\
(\text { Prob > chi2) }\end{array}$ & $\begin{array}{c}452 \\
-495.04 \\
151.10 \\
(0.000) \\
\end{array}$ & $\begin{array}{c}427 \\
-495.35 \\
200.20 \\
(0.000) \\
\end{array}$ & $\begin{array}{c}450 \\
-240.17 \\
30.53 \\
(0.000) \\
\end{array}$ & $\begin{array}{c}334 \\
-299.37 \\
47.48 \\
(0.000) \\
\end{array}$ & $\begin{array}{c}441 \\
-488.16 \\
307.67 \\
(0.000) \\
\end{array}$ & $\begin{array}{c}463 \\
-930.27 \\
369.11 \\
(0.000) \\
\end{array}$ \\
\hline
\end{tabular}

Notes: * and ** refer to $5 \%$, and $1 \%$ level of statistical significance. P-values are in parentheses. The dependent variable is the patent count (successful and unsuccessful applications) in a given technological area. The coefficient on the intercept represents the average value of the countryspecific fixed effects. 


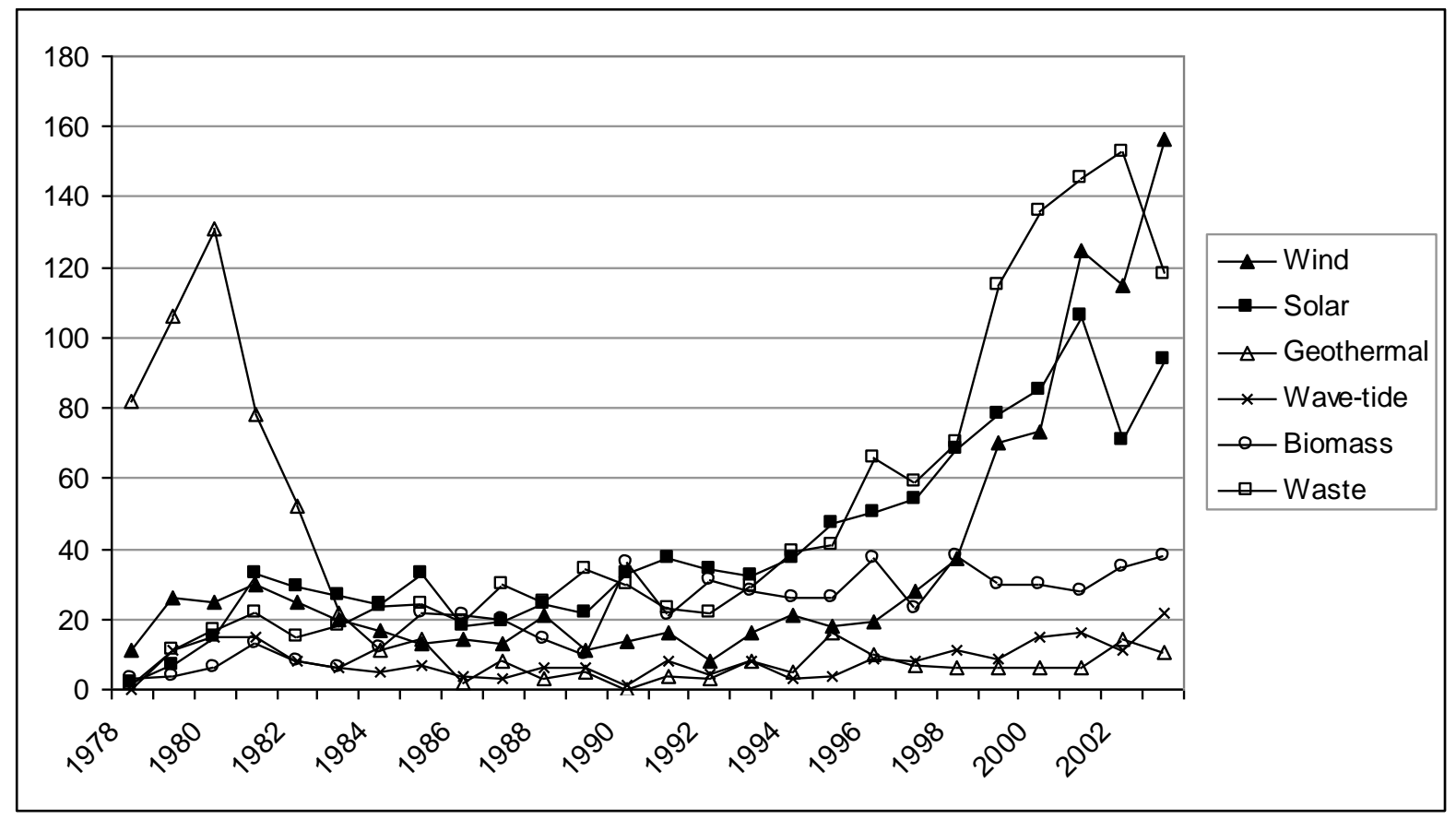

Figure 1. Number of EPO patent applications for renewables by type of technology

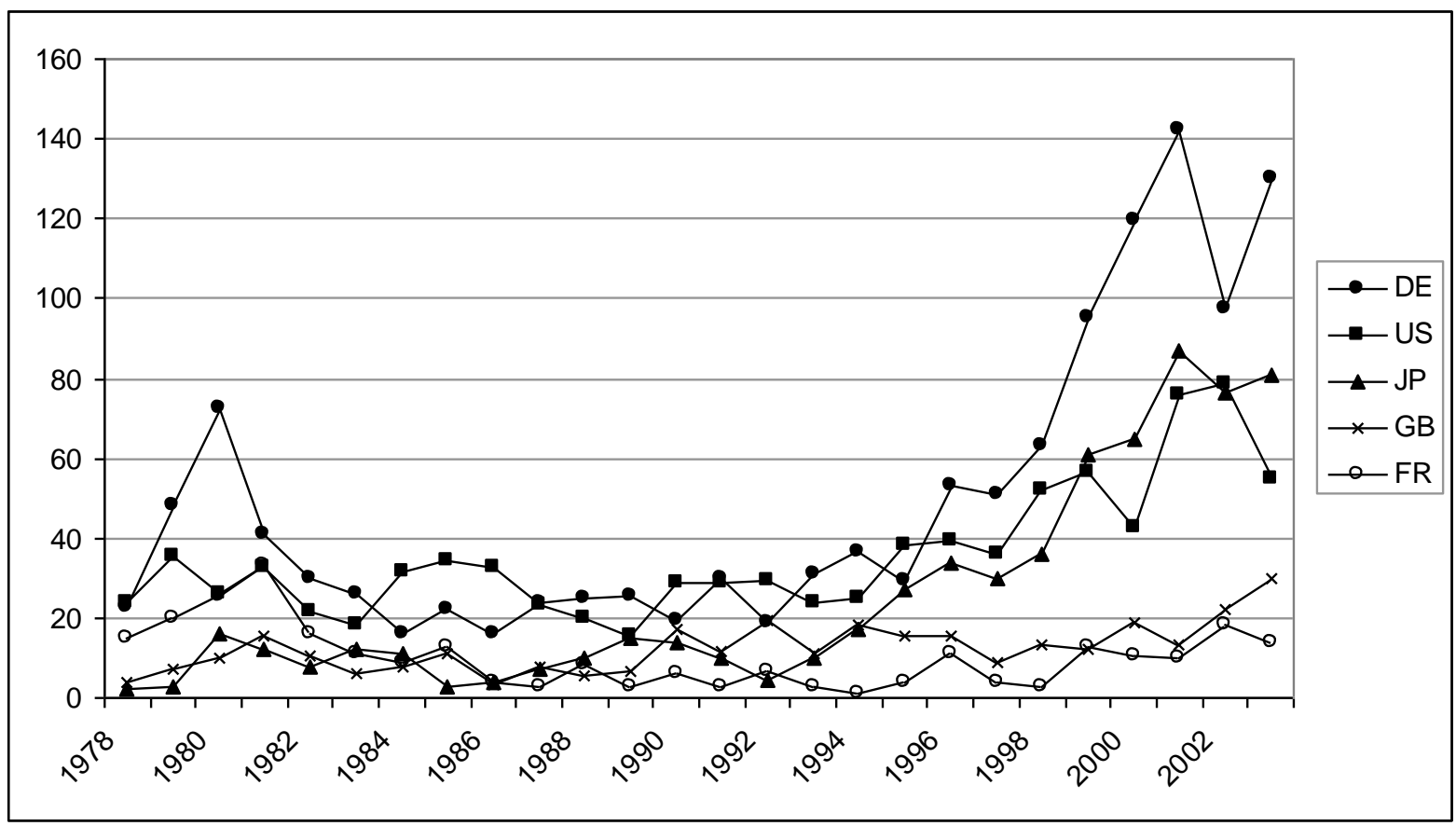

Figure 2. Number of EPO patent applications for renewables by country 


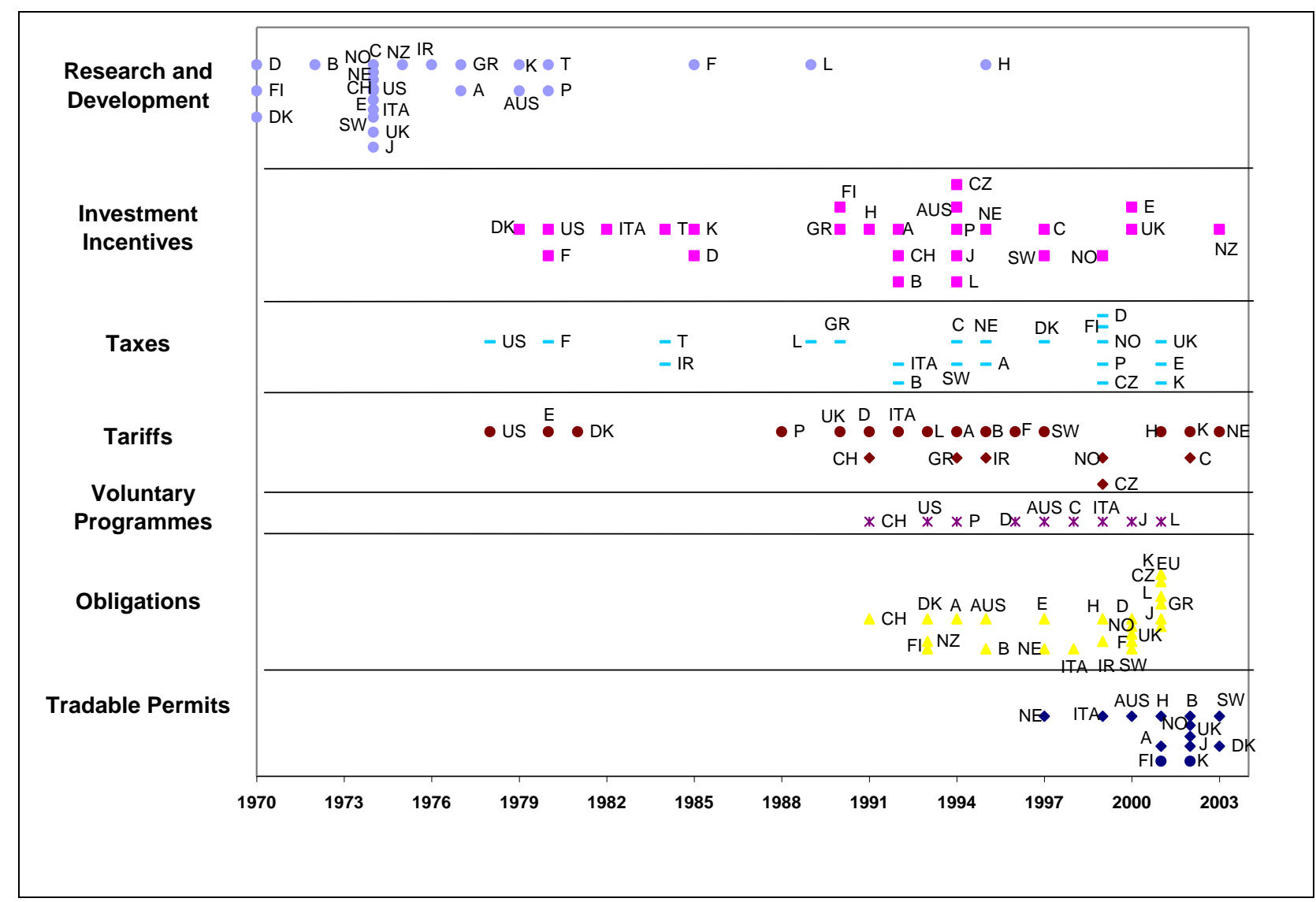

Source: IEA (2004) $)^{12}$

Figure 3. Introduction of renewable energy policies by type in OECD countries ${ }^{13}$

${ }^{12}$ An updated version of the table published in IEA (2004) was kindly provided by Piotr Tulej of the International Energy Agency.

${ }^{13}$ AUS - Australia, C - Canada, FI - Finland, GR - Greece, ITA - Italy, L - Luxembourg, NO Norway, SW - Sweden, UK - United Kingdom, A - Austria, CZ - Czech Rep., F - France, H Hungary J - Japan, NE - Netherlands, P - Portugal, CH - Switzerland, US - United States, B Belgium, DK - Denmark, DE - Germany, IR - Ireland, K-Korea, NZ - New Zealand, E - Spain, T Turkey. 


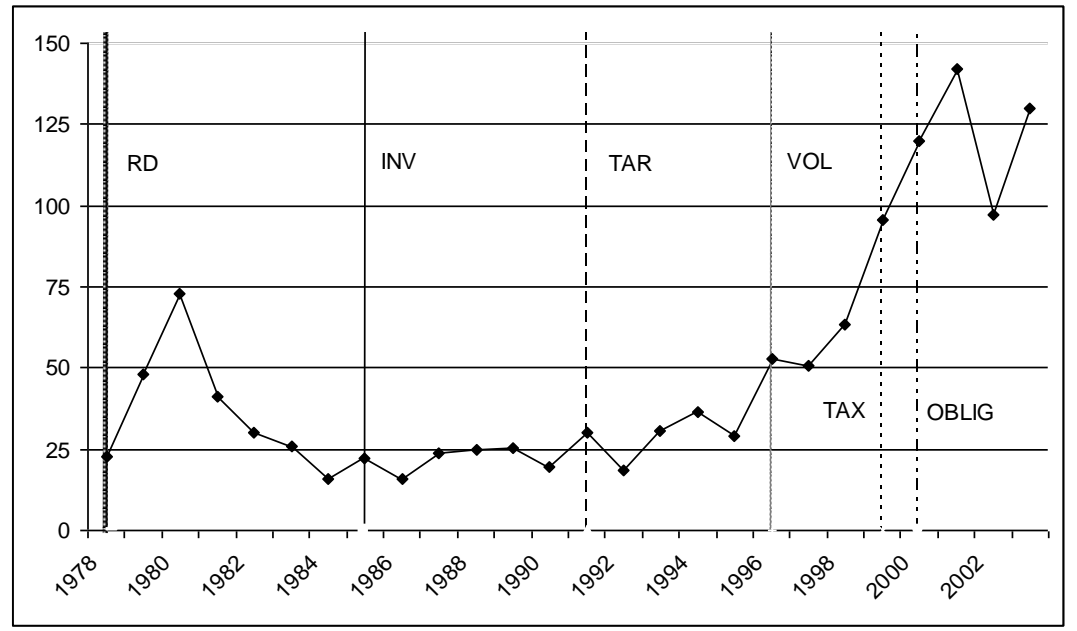

GERMANY

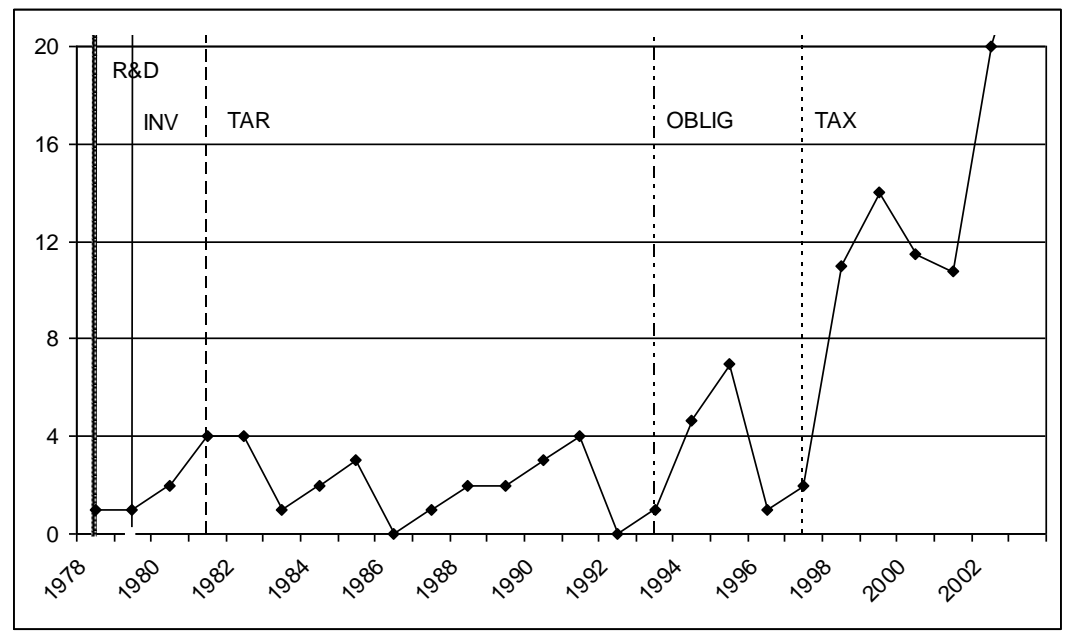

DENMARK

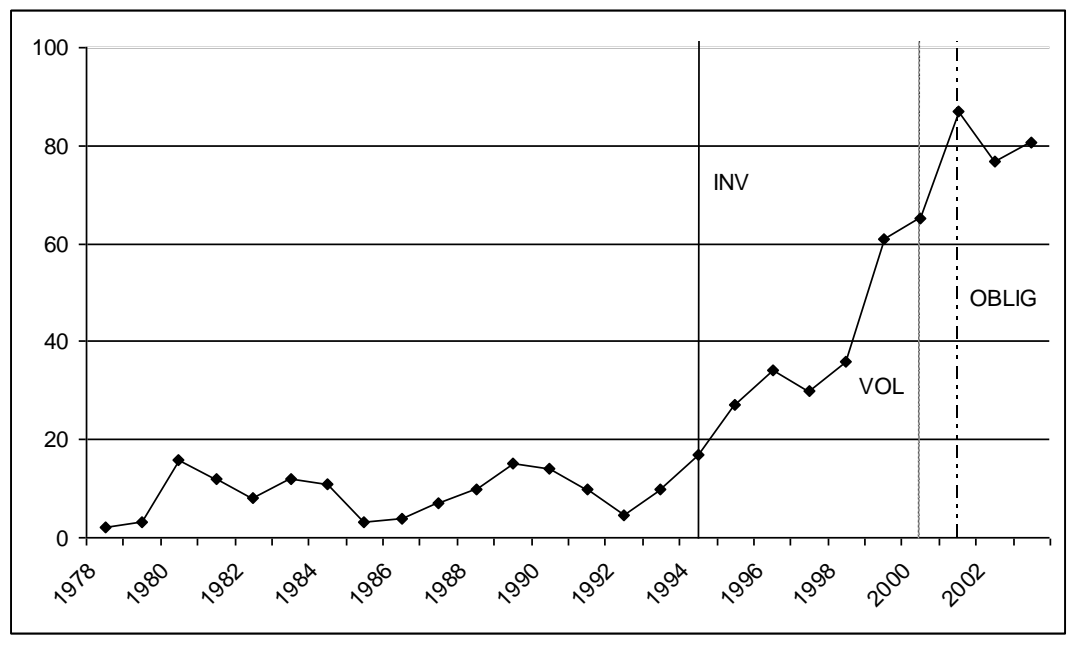

JAPAN

Figure 4. Relationship between point of introduction of policies and patent counts ${ }^{14}$

\footnotetext{
${ }^{14} \mathrm{RD}=$ Research and Development; INV=Investment Incentive; TAR=Tariff Structure; VOL=Voluntary Agreement; OBLIG=Obligation or Quota; TAX=Tax Incentive
} 


\section{APPENDIX. IPC codes for renewable energy technologies}

\begin{tabular}{|c|c|c|}
\hline WIND & Class & Sub-Classes \\
\hline Wind motors with rotation axis substantially in wind direction & F03D & $1 / 00-06$ \\
\hline Wind motors with rotation axis substantially at right angle to wind direction & F03D & 3/00-06 \\
\hline Other wind motors & F03D & $5 / 00-06$ \\
\hline Controlling wind motors & F03D & $7 / 00-06$ \\
\hline Adaptations of wind motors for special use; & F03D & $9 / 00-02$ \\
\hline $\begin{array}{l}\text { Details, component parts, or accessories not provided for in, or of interest apart from, the other } \\
\text { groups of this subclass }\end{array}$ & F03D & $11 / 00-04$ \\
\hline Electric propulsion with power supply from force of nature, e.g. sun, wind & B60L & $8 / 00$ \\
\hline Effecting propulsion by wind motors driving water-engaging propulsive elements & $\mathrm{B} 63 \mathrm{H}$ & $13 / 00$ \\
\hline \multicolumn{3}{|l|}{ SOLAR } \\
\hline Devices for producing mechanical power from solar energy & F03G & $6 / 00-08$ \\
\hline Use of solar heat, e.g. solar heat collectors & $\mathrm{F} 24 \mathrm{~J}$ & $2 / 00-54$ \\
\hline Machine plant or systems using particular sources of energy - sun & F25B & 27/00B \\
\hline $\begin{array}{l}\text { Drying solid materials or objects by processes involving the application of heat by radiation - } \\
\text { e.g. sun }\end{array}$ & F26B & $3 / 28$ \\
\hline $\begin{array}{l}\text { Semiconductor devices sensitive to infra-red radiation - including a panel or array of } \\
\text { photoelectric cells, e.g. solar cells }\end{array}$ & $\mathrm{H} 01 \mathrm{~L}$ & $31 / 042$ \\
\hline Generators in which light radiation is directly converted into electrical energy & $\mathrm{H} 02 \mathrm{~N}$ & $6 / 00$ \\
\hline Aspects of roofing for the collection of energy - i.e. solar panels & E04D & $13 / 18$ \\
\hline Electric propulsion with power supply from force of nature, e.g. sun, wind & $\mathrm{B} 60 \mathrm{~L}$ & $8 / 00$ \\
\hline \multicolumn{3}{|l|}{ GEOTHERMAL } \\
\hline $\begin{array}{l}\text { Other production or use of heat, not derived from combustion - using natural or geothermal } \\
\text { heat }\end{array}$ & F24J & 3/00-08 \\
\hline Devices for producing mechanical power from geothermal energy & F03G & $4 / 00-06$ \\
\hline Electric motors using thermal effects & $\mathrm{H} 02 \mathrm{~N}$ & $10 / 00$ \\
\hline \multicolumn{3}{|l|}{ OCEAN } \\
\hline $\begin{array}{l}\text { Adaptations of machines or engines for special use - characterized by using wave or tide } \\
\text { energy }\end{array}$ & F03B & $13 / 12-24$ \\
\hline Mechanical-power producing mechanisms - ocean thermal energy conversion & F03G & $7 / 05$ \\
\hline Mechanical-power producing mechanisms - using pressure differentials or thermal differences & F03G & $7 / 04$ \\
\hline Water wheels & F03B & $7 / 00$ \\
\hline \multicolumn{3}{|l|}{ BIOMASS } \\
\hline Solid fuels based on materials of non-mineral origin - animal or vegetable & C10L & $5 / 42-44$ \\
\hline Engines operating on gaseous fuels from solid fuel - e.g. wood & F02B & $43 / 08$ \\
\hline Liquid carbonaceous fuels - organic compounds & $\mathrm{C} 10 \mathrm{~L}$ & $1 / 14$ \\
\hline Anion exchange - use of materials, cellulose or wood & B01J & $41 / 16$ \\
\hline \multicolumn{3}{|l|}{ WASTE } \\
\hline Solid fuels based on materials of non-material origin - refuse or waste & C10L & $5 / 46-48$ \\
\hline Machine plant or systems using particular sources of energy - waste & F25B & $27 / 02$ \\
\hline Hot gas or combustion - Profiting from waste heat of exhaust gases & F02G & $5 / 00-04$ \\
\hline Incineration of waste - recuperation of heat & $\mathrm{F} 23 \mathrm{G}$ & $5 / 46$ \\
\hline Plants or engines characterized by use of industrial or other waste gases & F012K & $25 / 14$ \\
\hline Prod. of combustible gases - combined with waste heat boilers & C10J & $3 / 86$ \\
\hline Incinerators or other apparatus consuming waste - field organic waste & $\mathrm{F} 23 \mathrm{G}$ & $7 / 10$ \\
\hline Manufacture of fuel cells - combined with treatment of residues & $\mathrm{H} 01 \mathrm{M}$ & $8 / 06$ \\
\hline
\end{tabular}

